\title{
FREQUENCY OF SPONTANEOUS BACTERIAL PERITONINTIS IN CHRONIC LIVER DISEASE PATIENTS USING PROTON PUMP INHIBITORS.
}

\footnotetext{
1. FCPS (Medicine) Senior Registrar Medicine Shalamar Hospital, Lahore.

2. FCPS (Gastroenterology) Registrar Hepatobiliary Shaikh Zayed Hospital Lahore.

3. M.Phil (Microbiology) Consultant Molecular Biologist Shalamar Hospital, Lahore.
}

Correspondence Address: Dr. Tahir Ullah Khan

Department of Medicine Unit II Shalamar Hospital, Lahore. tahirnurar69@gmail.com

Article received on: 15/11/2018 Accepted for publication: $24 / 04 / 2019$

\begin{abstract}
Tahir Ullah Khan ${ }^{1}$, Wali Khan ${ }^{2}$, Sajjad Iqbal ${ }^{3}$
\end{abstract}
\begin{abstract}
Objectives: To determine the frequency of spontaneous bacterial peritonitis (SBP) in chronic liver disease patients with ascites using proton pump inhibitors (PPI). Study Design: Prospective cohort study. Setting: Medicine Unit-II, Shalamar Hospital Lahore. Period: From $1^{\text {st }}$ January to $30^{\text {th }}$ June 2017 . Materials \& Methods: A total of 380 patients enrolled in present study were divided into two groups; PPI group and non PPI group. Each group had 190 patients. We performed an extensive matching in both groups to minimize selection bias and SBP incidence was compared in both groups. Multivariate analysis was applied to sort out the causal relationship between PPI use and SBP. Results: Applying strict exclusion criteria, SBP incidence in chronic liver disease patients with ascites was found significantly high in PPI group than non-PPI group (12.63\% vs. 6.84\%, P Value 0.002$)$. Moreover, a large no of patients (39.47\%) were using PPI for inappropriate indications while acid peptic disease was the most common indication for its use (60.53\%). Conclusion: Use of proton pump inhibitors in chronic liver disease patients with ascites significantly increases the risk of spontaneous bacterial peritonitis.
\end{abstract}

Key words: $\quad$ Spontaneous Bacterial Peritonitis, Chronic Liver Disease, Proton Pump Inhibitors.

Article Citation: Khan T, Khan W, lqbal S. Frequency of spontaneous bacterial peritonintis in chronic liver disease patients using proton pump inhibitors. Professional Med J 2020; 27(3):455-460. DOI: 10.29309/TPMJ/2020.27.3.968

\section{INTRODUCTION}

Cirrhosis of liver is a chronic diffuse liver disease characterized by distortion of normal liver architecture and replacement by nodular regeneration and fibrosis. It is widely prevalent in Europe and contributes about 1.5 to $2 \%$ of overall mortality in the region. ${ }^{1}$ It ranks $12^{\text {th }}$ among the leading causes of death in the United States, but even this high mortality is still believed to be an underestimation and more research is needed. ${ }^{2}$ One third of the patients with decompensated cirrhosis die within one month and another $30 \%$ succumb to death during the first year after onset of infections particularly spontaneous bacterial peritonitis. ${ }^{3,4}$ It is the most frequent and fatal infection in cirrhotic patients and a consequence of frequent alterations in intestinal flora, pathological bacterial translocation and increased intestinal permeability. ${ }^{5}$ Small intestinal bacterial overgrowth (SIBO) and impaired immunity play a vital role in development of bacterial translocation. Invasive procedures such as paracentesis also contribute to SBP acquired during hospital stay. ${ }^{6-8}$

Currently, Proton pump inhibitors are one of the most commonly prescribed drugs and are used in a variety of indications such as acid peptic disease, gastro-esophageal reflux disease, barret-esophagus, prophylaxis of stress ulcer and NSAID's induced ulcers. As a group, they have been considered to be safe drugs with very few unwanted effects. But over the last decade or so, their antacid action has been extensively studied and various adverse effects have been noted such as increased risk of pneumonia, increased fracture risk, nephrotoxicity, vitamin and mineral deficiencies and increased risk of cardiovascular events. ${ }^{9,10}$

Gastrointestinal acid acts as a primary defense mechanism against invasion of different microorganisms. Therefore, when Proton pump inhibitors neutralize the acidic environment via 
their antacid mechanism, the intestinal flora flourishes relentlessly leading to small intestinal bacterial over growth (SIBO) and hence an increased risk of SBP.11 However, the causal relationship between Proton pump inhibitors and Spontaneous bacterial peritonitis remains to be established.

The rationale of the study is to resolve the variability in the frequency of spontaneous bacterial peritonitis as present in the international published literature. There is no local study till now and findings of this study will be useful for our local population. As stated in the literature that frequency of the disease may change with change in geographical location, so we expect different results in our population. Moreover, the results of this study could be used for future guidelines and patient management plans.

\section{METHODOLOGY}

A total of 380 patients with chronic liver disease having ascites were enrolled to assess the frequency of spontaneous bacterial peritonitis. Half of them (190) had previous history of using proton pump inhibitors for more than two weeks while remaining half (190) were without proton pump inhibitors. Confidence interval was taken as $95 \%$ with $5 \%$ margin of error. Sample size was calculated using WHO formula.

The age range of both male and female patients was 25 to 60 years, having sonographically documented chronic liver disease, paracentesis proven SBP (>250 neutrophils $/ \mathrm{mm}^{3}$ ) and history of PPI use for at least two weeks. Patients excluded from our study were those who had gastrointestinal bleeding with recent drop in hemoglobin of $2 \mathrm{~g} / \mathrm{dl}$ or more. All the patients with organ transplantation history, those with history of antibiotic use within last 2 weeks and those with tuberculous or carcinomatous peritonitis were also excluded.

The etiology of liver cirrhosis in present study was based on chronic viral hepatitis B, C and alcohol use. Paracentesis was performed under aseptic conditions. Ascitic fluid specimens were inoculated into blood culture bottles and sent for analysis. Detail history was obtained regarding PPI dosage, duration, indications, adverse effects and patients were evaluated for SBP. All data was collected as per our designed Performa.

All collected data was analyzed using SPSS version 23. Qualitative data like gender, spontaneous bacterial peritonitis, was presented in the form of frequency and percentages. Quantitative data like age (years) was expressed in the form of mean \pm S.D. Data was stratified for type of hepatitis, age, gender and Child-Pugh class to deal with effect modifier. Post stratification chi square test was applied. P-value of 0.05 or less was taken as statistically significant.

\section{RESULTS}

In present study, a total of 380 patients were included. All the patients were divided into two groups, PPI group and non PPI group. Number of patients in each group was 190. Male gender was prominent in both groups $(58.42 \%$ in $\mathrm{PPI}$ group and $57.37 \%$ in non PPI group) $(p=0.56)$. There was no statistically significant difference in mean age of both groups $(p=0.69)$. Regarding etiology of chronic liver disease; most of the patients in both groups had chronic hepatitis C infection (51.58\% in PPI group and $52.63 \%$ in non PPI group) followed by hepatitis $B$ and non-viral alcoholic patients $(p=0.51)$ (Table-I).

There was no statistically significant difference in serum albumin, bilirubin, prothrombin time and Child-Pugh scoring of both groups (Table-I). The basic components of Child Pugh score are summarized in Table-II. In terms of PPI use, only115 (60.52\%) patients were using PPI according to standard recommendations. The remaining 75 patients (39.48\%) were using PPI for non-specific indications (Figure-1). Among first 115 patients, mostly were using PPI for acid peptic disease (60.86\%) followed by GERD (26.08\%), esophageal or gastric varices (8.69\%) and other indications (4.34\%) (Table-III).

Among 190 patients included in PPI group, 18 $(9.47 \%)$ had at least one episode of SBP during the 6 months of observation, while 6 (3.15\%) had two or more than two episodes of SBP. Among 
190 patients of non PPI group, only 11 (5.78\%) patients had at least one episode of SBP during 6 months while only 2 patients (1.05\%) had two or more than two episodes of SBP $(p=0.04)$ (Figure-2).

\begin{tabular}{|l|c|c|c|}
\hline \multicolumn{1}{|c|}{ Variables } & PPI Group $(\mathbf{n = 1 9 0 )}$ & Non PPI Group $(\mathbf{n = 1 9 0 )}$ & P-Value \\
\hline Age (Mean \pm SD) & $46.90 \pm 10.2$ & $47.01 \pm 10.1$ & 0.699 \\
\hline Gender & $111(58.42 \%)$ & $109(57.37 \%)$ & 0.569 \\
Male & $79(41.58 \%)$ & $81(42.63 \%)$ & \\
Female & & & \\
\hline Etiology of liver disease & $98(51.58 \%)$ & $100(52.63 \%)$ & 0.516 \\
HCV & $82(43.16 \%)$ & $79(41.58 \%)$ & \\
HBV & $10(5.26 \%)$ & $11(5.79 \%)$ & 0.78 \\
\hline Alcohol & $8.01 \pm 1.7$ & $7.99 \pm 1.7$ & 0.39 \\
\hline Child-Pugh score & $2.8 \pm 0.8$ & $2.9 \pm 0.7$ & 0.48 \\
\hline Albumin & $2.9 \pm 4.9$ & $2.5 \pm 3.99$ & 0.0038 \\
\hline Bilirubin & $1.3 \pm 0.5$ & $1.3 \pm 0.4$ & \\
\hline Prothrombin time & & & \\
\hline
\end{tabular}

Table-I. Comparison of baseline characteristics

\begin{tabular}{|l|c|c|c|}
\hline \multicolumn{1}{|c|}{ Parameters } & Points Assigned & & \\
\hline Ascites & $\mathbf{1}$ & $\mathbf{2}$ & $\mathbf{3}$ \\
\hline Hepatic encephalopathy & Absent & Slight & Moderate \\
\hline Bilirubin, $\mathrm{mg} / \mathrm{dl}$ & None & Grade $1-2$ & $>3$ \\
\hline Albumin, $\mathrm{g} / \mathrm{dl}$ & $<2$ & $2-3$ & $<2.8$ \\
\hline Prothombin time (seconds over control) & $>3.5$ & $2.8-3.5$ & $>6$ \\
\hline INR & $<4$ & $4-6$ & $>2.3$ \\
\hline
\end{tabular}

CPT classification: Child A: score 5-6 (well compensated); Child B: score 7-9 (significant functional compromise); Child C: score 10-15 (decompensated)

Table-II. Child-Pugh score

\begin{tabular}{|l|c|c|}
\hline \multicolumn{1}{|c|}{ Indication for PPI Use } & No of Patients $(\boldsymbol{n}=115)$ & Percentage \\
\hline Acid peptic disease & 70 & $60.86 \%$ \\
\hline GERD & 30 & $26.08 \%$ \\
\hline Esophageal or gastric varices & 10 & $8.69 \%$ \\
\hline Other indications & 5 & $4.34 \%$ \\
\hline
\end{tabular}

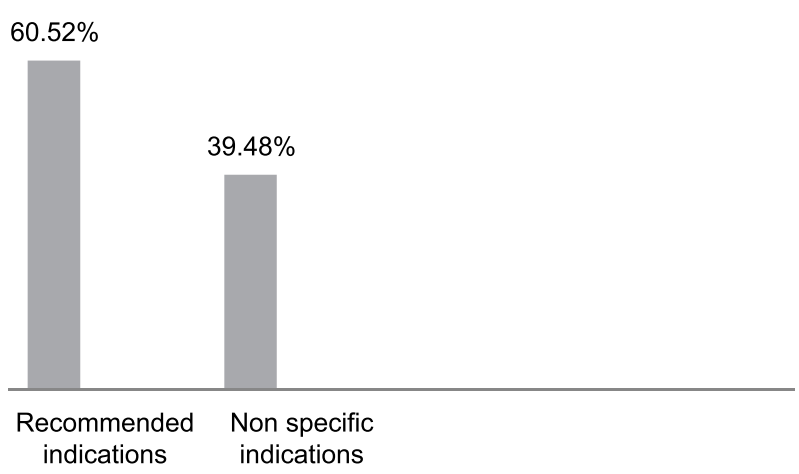

Figure-1. Indications for PPI use according to standard protocols

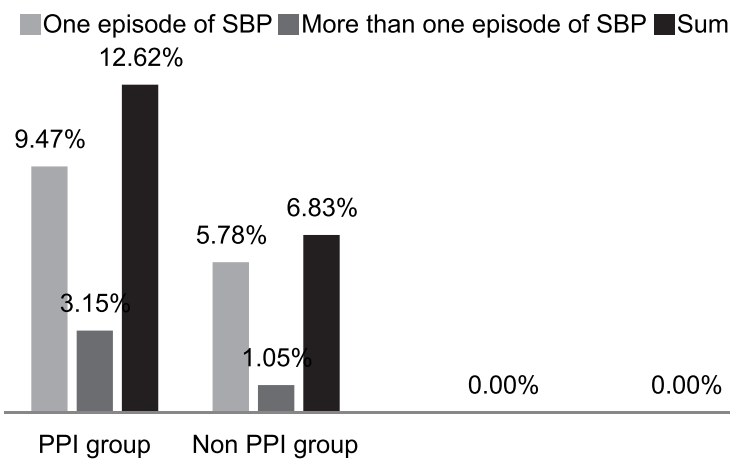

Figure-2. SBP incidence in PPI and non PPI groups 


\section{DISCUSSION}

Onset of spontaneous bacterial peritonitis in chronic liver disease patients is an alarming sign and carries a high morbidity and mortality in these patients. The major predisposing factor to SBP in these patients is small intestinal bacterial overgrowth. ${ }^{12,13}$ Proton pump inhibitors allow microorganisms to grow within the gastrointestinal tract via its antacid action and neutralization of acidic environment. These microorganisms then lead to SBP in cirrhotic patients. ${ }^{14,15}$

Majority of the studies conducted on proton pump inhibitors and their role in spontaneous bacterial peritonitis are case control studies which failed to establish a definite causal relationship between the two. Furthermore, study of Campbell and his colleagues raised doubts on this association. ${ }^{16}$ Therefore it was necessary to conduct a large cohort study to establish a causal relationship between Proton pump inhibitors and Spontaneous bacterial peritonitis. We performed an extensive matching in both groups to make sure that there is no selection bias and no confounders affect our study results.

Findings of this study showed that incidence of SBP in chronic liver disease patients using PPI were significantly high (two fold) in PPI group as compared to non PPI group (12.62\% in PPI group and $6.83 \%$ in non PPI group). Regarding more than one episode of SBP, PPI users were having three fold increased risk as compared to non PPI group (3.15\% in PPI group and $1.05 \%$ in non PPI group). Moreover, an appreciable number of patients (39.48\%) were using PPI for inappropriate indications. Most of the patients (60.86\%) were using PPI for acid peptic disease. A similar cohort study but with a large sample size was conducted in 2009 which showed that use of Proton pump inhibitors is strongly linked with development of SBP and should only be used where appropriate. ${ }^{17}$ Their results were close to our study. In another study, Bajaj and his colleagues noted that frequency of SBP was 69\% (almost three fold high risk) among cirrhotic patients who were using PPI. ${ }^{18}$ According to a study conducted in Taiwan, incidence of SBP in cirrhotic patients using proton pump inhibitors was almost two times higher as compared to control group. ${ }^{19}$ Another study conducted in Ohio USA showed a statistically significant association between PPI and SBP, but it also emphasized that this association is quantitatively small. ${ }^{20} \mathrm{~A}$ meta-analysis carried out in China in 2015 further strengthened the causal relationship of PPI and SBP in chronic liver disease patients. ${ }^{21}$ There were some limitations in the present study. Firstly, PPI dosage was not taken into consideration. It is theoretically possible that high dose PPI may be associated with increased risk of SBP as compared to small dosage. ${ }^{22}$ Secondly, our study was based on small sample size. In order to establish the causal relationship between PPI and SBP beyond any doubt, large sample sized prospective cohort studies are needed. Thirdly, duration of PPI use in our study was short term (2 weeks), but even this short term use of PPI significantly increased the risk of SBP in our patients. It will be interesting to know in future whether the patients on long term PPI are more prone to SBP or not.

\section{CONCLUSION}

Use of proton pump inhibitors in chronic liver disease patients with ascites significantly increases the risk of spontaneous bacterial peritonitis. So, inappropriate use of proton pump inhibitors in chronic liver disease patients should be avoided to minimize the risk of SBP in these patients.

\section{Copyright $(24$ Apr, 2019.}

\section{REFERENCES}

1. Blachier M, Leleu H, Peck-Radosavljevic M, Valla DC, Roudot-Thoraval F. The burden of liver disease in Europe: a review of available epidemiological data. Journal of hepatology. 2013 Mar 1;58(3):593-608. doi: 10.1016/j.jhep.2012.12.005.

2. Asrani SK, Larson JJ, Yawn B, Therneau TM, Kim WR. Underestimation of liver-related mortality in the United States. Gastroenterology. 2013 Aug 1;145(2):375-82.Doi: 10.1053/j.gastro.2013.04.005.

3. Arvaniti V, D'Amico G, Fede G, Manousou P, Tsochatzis $E$, Pleguezuelo $M$, Burroughs $A K$. Infections in patients with cirrhosis increase mortality four-fold and should be used in determining prognosis. Gastroenterology. 2010 Oct 1;139(4):1246-56. Doi: 10.1053/j.gastro.2010.06.019. 
4. Jalan R, Fernandez J, Wiest R, Schnabl B, Moreau R, Angeli P, Stadlbauer V, Gustot T, Bernardi M, Canton R, Albillos A. Bacterial infections in cirrhosis: a position statement based on the EASL Special Conference 2013. Journal of hepatology. 2014 Jun 1;60(6):1310-24. Doi: 10.1016/j.jhep.2014.01.024.

5. Reiberger T, Ferlitsch A, Payer BA, Mandorfer M, Heinisch BB, et al. (2013) Non-selective beta blocker therapy decreases intestinal permeability and serum levels of LBP and IL-6 in patients with cirrhosis. J Hepatol 58: 911-21. Doi: 10.1016/j.jhep.2012.12.011.

6. Wiest R, Krag A, Gerbes A. Spontaneous bacterial peritonitis: Recent guidelines and beyond. Gut 2012; 61: 297-310.

7. Obstein KL, Campbell MS, Reddy KR, Yang YX. Association between model for end-stage liver disease and spontaneous bacterial peritonitis. Am J Gastroenterol 2007; 102: 2732-6.

8. Kheloufi F, Frankel D, Kaspi E, Lepelley M, Mallaret M, Boucherie Q, Roll P, Micallef J. Chronic use of proton pump inhibitors, adverse events and potential biological mechanisms: A translational analysis. Therapies. 2018 May 1;73(3):273-81. Doi: 10.1016/j. therap.2017.08.003. [Epub ahead of print].

9. Corsonello A, Lattanzio F, Bustacchini S, Garasto S, Cozza A, Schepisi R, Lenci F, Luciani F, Maggio MG, Ticinesi A, Butto V. Adverse events of proton pump inhibitors: potential mechanisms. Current drug metabolism. 2018 Feb 1;19(2):142-54. Doi: 10.2174/138 9200219666171207125351. \{Epub ahead of print\}.

10. Trikudanathan G, Israel J, Cappa J, O'Sullivan DM. Association between proton pump inhibitors and spontaneous bacterial peritonitis in cirrhotic patients - a systematic review and meta-analysis. Int J ClinPract 2011; 65: 674-8.

11. Chang CS, Chen GH, Lien HC, Yeh HZ. Small intestine dysmotility and bacterial overgrowth in cirrhotic patients with spontaneous bacterial peritonitis. Hepatology 1998; 28: 1187-90. Wiley Online Library | PubMed | CAS | Web of Science ${ }^{\circledR}$ Times Cited: 11218.

12. Guarner C, Runyon BA, Young S, Heck M, Sheikh MY. Intestinal bacterial overgrowth and bacterial translocation in cirrhotic rats with ascites. J Hepatol 1997; 26: 1372-8. CrossRef | PubMed | CAS | Web of Science ${ }^{\circledR}$ Times Cited: 120.
13. Pardo A, Bartolí R, Lorenzo-Zúñiga V, Planas R, Viñado B, Riba J, Cabré E, Santos J, Luque T, Ausina V, Gassull MA. Effect of cisapride on intestinal bacterial overgrowth and bacterial translocation in cirrhosis. Hepatology. 2000 Apr;31(4):858-63. Wiley Online Library | PubMed | CAS | Web of Science ${ }^{\circledR}$ Times Cited: 89.

14. Lewis SJ, Franco S, Young G, O'KEEFE SJ. Altered bowel function and duodenal bacterial overgrowth in patients treated with omeprazole. Alimentary pharmacology \& therapeutics. 1996 Aug;10(4):55761. Wiley Online Library | PubMed | CAS | Web of Science ${ }^{\circledR}$ Times Cited: 5617.

15. Goel GA, Deshpande A, Lopez R, Hall GS, van Duin $D$, Carey WD. Increased rate of spontaneous bacterial peritonitis among cirrhotic patients receiving pharmacologic acid suppression. ClinGastroenterolHepatol 2012; 10: 4227. CrossRef | CAS | Web of Science ${ }^{\circledR}$ Times Cited: 12.

16. Campbell MS, Obstein $\mathrm{K}$, Reddy KR, Yang $\mathrm{YX}$. Association between proton pump inhibitor use and spontaneous bacterial peritonitis. Dig Dis Sci 2008; 53: 394-8.

17. Min YW, Lim KS, Min BH, Gwak GY, Paik YH, Choi MS, Lee JH, Kim JJ, Koh KC, Paik SW, Yoo BC, Rhee $P L$. Proton pump inhibitor use significantly increases the risk of spontaneous bacterial peritonitis in 1965 patients with cirrhosis and ascites: A propensity score matched cohort study. Aliment PharmacolTher 2014; 40: 695-704.

18. Bajaj JS, Zadvornova Y, Heuman DM, Hafeezullah M, Hoffmann RG, Sanyal AJ, Saeian K. Association of proton pump inhibitor therapy with spontaneous bacterial peritonitis in cirrhotic patients with ascites. AmJ Gastroenterol. 2009; 104(5):1130-4. Doi: 10.1038/ ajg.2009.80.

19. Huang KW, Kuan YC, Luo JC, Lin CL, Liang JA, Kao $\mathrm{CH}$. Impact of long-term gastric acid suppression on spontaneous bacterial peritonitis in patients with advanced decompensated liver cirrhosis. Eur J Intern Med. 2016 Jul; 32:91-5. Doi: 10.1016/j.ejim.2016.04.016. Epub 2016 Apr 29.

20. Khan MA, Kamal S, Khan S, Lee WM, Howden CW. Systematic review and meta-analysis of the possible association between pharmacological gastric acid suppression and spontaneous bacterial peritonitis. Eur J Gastroenterol Hepatol. 2015 Nov; 27(11):1327-36. Doi: 10.1097/MEG.0000000000000448. 
21. Xu HB, Wang HD, Li CH, Ye S, Dong MS, Xia QJ, Zhang $A Q$, Pan K, Ge XL, Dong JH Proton pump inhibitor use and risk of spontaneous bacterial peritonitis in cirrhotic patients: A systematic review and metaanalysis Genet Mol Res. 2015 Jul 6;14(3):7490-501. Doi: 10.4238/2015.July.3.25.
22. Corleto VD, Festa S, Di Giulio E, Annibale B. Proton pump inhibitor therapy and potential long-term harm. Curr Opin Endocrinol Diabetes Obes. 2014 Feb; 21(1):3-8. Doi: 10.1097/MED.0000000000000031.

\section{AUTHORSHIP AND CONTRIBUTION DECLARATION}

\begin{tabular}{|c|c|c|c|}
\hline Sr. \# & Author(s) Full Name & Contribution to the paper & Author(s) Signature \\
\hline 1 & Tahir Ullah Khan & $\begin{array}{l}\text { Data collection, article writting / } \\
\text { Finalization. }\end{array}$ & $\int_{23 / 4 / 2027}$ \\
\hline 2 & Wali Khan & $\begin{array}{l}\text { Manuscript design and review, } \\
\text { Literature review. }\end{array}$ & $w$ \\
\hline 3 & Sajjad Iqbal & Final review \& Proof reading. & $S \in G$ \\
\hline
\end{tabular}

